\title{
ABOUT THE ASSESSMENT OF MAIN CONTENT OF STUDENT'S ACTIVITY ACCORDING THE SUB-STANDARDS GRADES
}

\author{
Nabi Mahmudov \\ $\mathrm{PhD}$ in mathematical and physical sciences, \\ Baku city, director of school-lyceum 246 \\ E-mail: nabimm@mail.ru \\ https://orcid.org/ 0000-0003-4351-9104
}

\begin{abstract}
The article discusses the assessment of student performance based on subclass standards for the main content standard. For the first time, it is proposed to establish a link between the levels of student's skills during the development of rubrics on the assessment of the same content standards on the basis of sub-content standards for classes, and examples are given. Examples of holistic rubrics are also provided to assess student's performance in the areas of demonstration and presentation. Thus, a teacher who admits students in the first grade at the primary level has been in contact with them for four years in a row, so by following their activities each school year, they can accurately determine their level of progress in the next grade.
\end{abstract}

Keywords: elementary class, activity tracking, rubric, rubric levels, inter-rubric connection by classes.

\section{DOI:}

To cite this article: Mahmudov N. (2021). About the assessment of main content of student's activity according the sub-standards grades. Journal of Preschool and Primary Education, Vol. 237, Issue IV, pp. 23-32

Article history: received - 28.10.2021; accepted - 18.11.2021. 


\title{
SAGIRD FOALIYYOTININ OSAS MOZMUN STANDARTLARININ SINIFLOR ÜZRӘ ALT STANDARTLAR OSASINDA QIYMOTLONDİRILMOSİ BARӘDə
}

\author{
Nəbi Mahmudov \\ fizika-riyaziyyat elmləri üzrə fəlsəfə doktoru, \\ Bak1 şəhəri, 246 №-li məktəb-liseyin direktoru \\ E-mail: nabimm@mail.ru \\ https://orcid.org/ 0000-0003-4351-9104
}

\begin{abstract}
Annotasiya. Məqalədə şagird fəaliyyətinin əsas məzmun standartlarının siniflər üzrə alt standartları əsasında qiymətləndirilməsindən söhbət gedir. İlk dəfə olaraq şagirdlərin bacarıq səviyyələrinin eyni məzmun standartlarının siniflər üzrə alt məzmun standartları əsasında qiymətləndirilməsi üzrə rubriklərin hazırlanması zamanı onların səviyyələri arasında əlaqənin yaradılması təklif olunur və nümunələr verilir. Nümayişetdirmə, təqdimetmə aspektləri üzrə şagirdlərin fəaliyyətinin qiymətləndirilməsi üçün holistik rubrik nümunələri də təqdim olunur. Beləliklə, ibtidai təhsil səviyyəsində şagirdləri birinci sinifdə qəbul edən müəllim onlarla dörd il ardıcıl təmasda olduğu üçün hər növbəti dərs ilində onların fəaliyyətini izləyərək, əvvəlki sinifdə onların bacarıqlarını nəzərə alır və sonrak1 sinifdə irəliləmə səviyyələrini düzgün müəyyən edə bilir.
\end{abstract}

Açar sözlər: ibtidai sinif, fəaliyyətin izlənilməsi, rubrik, rubrik səviyyələri, siniflər üzrə rubriklərarası əlaqə.

\section{DOI:}

Məqaləyə istinad: Mahmudov N. (2021). Şagird fəaliyyətinin əsas məzmun standartlarının siniflər üzrə alt standartlar əsasında qiymətləndirilməsi barədə. «Məktəbəqədər və ibtidai təhsil», № 4 (237), səh. 23-32

Məqalə tarixçəsi: göndərilib - 28.10.2021; qəbul edilib - 18.11.2021. 


\section{Giriş / Introduction}

Azərbaycan xalqının ümummilli lideri Heydər Oliyev millətin gələcəyini onun təhsilində görürdü və onun 1999-cu ildə "Azərbaycan Respublikasının təhsil sahəsində İslahat Proqramı"nın qəbul edilməsi ilə bağlı imzaladığı sərəncamla ölkəmizin təhsil sistemində islahatların aparılmasına start verildi. Bu məqsədlə, Azərbaycan hökuməti ilə Dünya İnkişaf Assosiasiyası arasında kredit sazişi imzalandı və müvafiq fəaliyyət planı hazırlandı. 2006-cı ildə Azərbaycan Respublikası Nazirlər Kabinetinin qərarı ilə "Azərbaycan Respublikasında ümumi təhsilin Konsepsiyası (Milli Kurikulumu)" təsdiq olundu. Bu milli kurikulum əsasında ibtidai təhsil səviyyəsinin I sinifləri üçün tərtib olunmuş dərslik nümunələri təhsil nazirinin əmri ilə 2007/2008-ci tədris ilində ölkənin seçilmiş ümumtəhsil məktəblərində eksperiment qaydasında tədris edildi. Aparılan eksperimentin nəticələri təhlil edilərək ümumiləşdirildi və növbəti tədris ilindən başlayaraq yeni dərsliklərin tətbiq olunması haqqında qərar verildi.

\section{Osas hissə / Main part}

2008/2009-cu tədris ilindən başlayaraq respublikanın ümumtəhsil məktəblərinin I siniflərində təlim prosesi yeni təhsil standartları və proqramları (kurikulumlar) əsasında yazılmış yeni dərslik komplektlərindən - şagirdlər üçün dərsliklər və müəllimlər üçün metodik vəsaitlərdən istifadə olunmaqla həyata keçirilməyə başlandı. Yeni dərslik komplektlərinin tətbiq edilməsi bu siniflərdə şagirdlərin tədris (cari, gündəlik) fəaliyyəti və tədris vahidləri (bölmələr, fəsillər) üzrə nailiyyət səviyyələrinin qiymətləndirilməsi üçün yeni normativ hüquqi sənədlərin hazırlanmasını zəruri etdi. "Azərbaycan Respublikasının ümumi təhsil sistemində Qiymətləndirmə Konsepsiyası" hazırlandı və hökumət tərəfindən qəbul olundu. 2013-2018-ci illərdə yeni fənn kurikulumlarının istifadə olunduğu siniflərdə şagirdlərin bacarıq və nailiyyət səviyyələrinin qiymətləndirilməsi "Ümumi təhsil məktəblərində məktəbdaxili qiymətləndirmənin aparılması üçün müvəqqəti Təlimat" əsasında həyata keçirildi [Ümumi təhsil məktəblərində məktəbdaxili qiymətləndirmənin aparılmasına dair müvəqqəti Təlimat. 2013]. Bu siniflərdə şagirdlərin gündəlik qiymətləndirilməsi ənənəvi 5 ballıq qiymətləndirmə sistemi ilə deyil, fəaliyyətin sözlə qiymətləndirilməsi şəklində aparılır. Sözlə qiymətləndirmə şagirdin fəaliyyətinin müəllim tərəfindən müvafiq məzmun standartına uyğun təyin olunmuş təlim məqsədləri əsasında izlənilməsidir. Bu, onun dərsdə əldə etdiyi biliklərin bacarığa çevrilmə səviyyəsinin müəyyən edilməsi yolu 


\section{http://ppe-journal.edu.az}

ilə aparılır. Bunun üçün müəllim tərəfindən dörd səviyyəli (I-IV səviyyələrdə) rubriklər hazırlanır. Burada I səviyyə şagirdin mənimsəyəcəyi biliyin bacarı̆̆a çevrilməsinin ən aşağı, IV səviyyə isə ən yüksək səviyyəsini təyin edir. Aralıq səviyyələr adlanan II-III səviyyələr isə I və IV səviyyələrə əsasən müəyyən olunur. Bu zaman şagirdin II (III, IV) səviyyə üzrə bacarıq səviyyəsinin onun I səviyyəyə aid bacarıq səviyyəsindən iki (üç, dörd) dəfə üstün olduğu qəbul edilir. Analoji olaraq, II (III, IV) səviyyəyə aid qiymətləndirmə tapşırığının I səviyyəyə aid qiymətləndirmə tapşırı̆̆ından iki (üç, dörd) dəfə çətin olduğu nəzərə alınır. 2018-ci il, dekabr ayının 28-dən etibarən təhsilalanların məktəbdaxili qiymətləndirilməsi "Ümumi təhsil pilləsində təhsilalanların attestasiyas1nın (məktəbdaxili qiymətləndirmə) aparılması Qaydası" ilə tənzimlənir [Ümumi təhsil pilləsində təhsilalanların attestasiyasının (məktəbdaxili qiymətləndirmə) aparılmas1 Qaydas1, 2018].

Biz şagirdin təlim fəaliyyətinin eyni əsas məzmun standartının ardıcıl siniflər üzrə alt məzmun standartları əsasında izlənilməsi və bacarıq səviyyəsinin qiymətləndirilməsi üçün tərtib edilən rubriklərin səviyyələri arasında əlaqəni təyin edəcəyik. Bu məqsədlə, əvvəlcə "I. Odədlər və əməllər" məzmun xəttinin I-IV siniflər üzrə 1.1. əsas və onların müvafiq alt məzmun standartlarını nəzərdən keçirək (cədvəl 1) [Ümumi təhsilin fənn standartları (I-XI siniflər), 2012].

Cədvəl 1

\begin{tabular}{|c|c|c|}
\hline \multicolumn{3}{|c|}{ Məzmun xətti: I. Әdədlər və əməllər } \\
\hline \multicolumn{3}{|c|}{ I-IX siniflər üzrə məzmun xəttinə aid əsas və alt məzmun standartları: } \\
\hline Sinif & Osas məzmun standart1 & Alt məzmun standart1 \\
\hline I & $\begin{array}{l}\text { - şagird say və ədəd anlayışlarını, } \\
\text { onlar arasındakı əlaqəni başa } \\
\text { düşdüyünü nümayiş etdirir. }\end{array}$ & \begin{tabular}{|l|}
1.1 .3 - şagird 20 \\
dairəsində ədədləri \\
oxuyur və yazır.
\end{tabular} \\
\hline II & $\begin{array}{l}\text { - şagird ədəd anlayışını, ədədin } \\
\text { strukturunu, ədədlər arasındakı } \\
\text { münasibətləri başa düşdüyünü } \\
\text { nümayiş etdirir. }\end{array}$ & $\begin{array}{l}1.1 .1 \text { - şagird } 100 \\
\text { dairəsində } \\
\text { ədədləri oxuyur və yazır. }\end{array}$ \\
\hline III & $\begin{array}{l}1.1 \text { - şagird ədəd anlayışını, ədədin } \\
\text { strukturunu, ədədlər arasındakı } \\
\text { münasibətləri başa düşdüyünü } \\
\text { nümayiş etdirir. }\end{array}$ & $\begin{array}{l}1.1 .1 \quad-\quad \text { şagird } 1000 \\
\text { dairəsində ədədləri oxuyur } \\
\text { və yazır. }\end{array}$ \\
\hline
\end{tabular}




\begin{tabular}{|c|l|l|}
\hline IV & $\begin{array}{l}1.1 \text { - şagird ədəd anlayışını, ədədin } \\
\text { strukturunu, ədədlər arasındakı } \\
\text { münasibətləri başa düşdüyünü və } \\
\text { sadə kəsrləri tanıdığını nümayiş } \\
\text { etdirir. }\end{array}$ & $\begin{array}{l}1.1 .1 \text { - şagird } 1000000 \\
\text { dairəsində ədədləri oxuyur } \\
\text { və yazır. }\end{array}$ \\
\hline
\end{tabular}

Qəbul olunmuş sənədlər əsasında tərtib edilmiş yuxarıdakı cədvəldən ümumi orta təhsil səviyyəsində riyaziyyat fənninin "Odədlər və əməllər" məzmun xəttinə aid əsas məzmun standartlarının, demək olar ki, eyni məzmunda tərtib olunduqları, sabit qaldıqları, lakin onların müvafiq alt məzmun standartlarının siniflər (və ya səviyyələr) üzrə qismən dəyişdiyi, başqa sözlə - ikinci sinifdən başlayaraq, hər bir alt məzmun standartının özündən əvvəlki standartın üzərində qurulduğu və onu inkişaf etdirdiyi - üfüqi istiqamətdə genişləndiyi, şaquli istiqamətdə dərinləşdiyi görünür. Daha dəqiq desək, şagird birinci sinifdə 20 dairəsində ədədlərlə tanış olduğu, onları onluq və təkliklərə ayırmaqla yazmağ1 və oxumağı nümayiş etdirmək bacarıqlarına yiyələndiyi halda, ikinci sinifdə bu proses 100, üçüncü sinifdə 1000, dördüncü sinifdə isə 1000000 dairəsində həyata keçirilir. Bu zaman tədris-təlim prosesi sadədən mürəkkəbə, asandan çətinə didaktik prinsipinə əməl olunmaqla qurulur. Şagird ardıcıl tədris illərində ədəd anlayışının mənasının genişləndirilməsi ilə yaxından tanış olur, onların mərtəbələrə (təkliklərə, onluqlara, yüzlüklərə) və siniflərə ayrılmasını öyrənir, yazılmasını, oxunmasını və aralarındakı qarşı1ıqlı əlaqələri mənimsəyir.

Aşağıda şagirdin eyni məzmun xəttinə aid əsas məzmun standartının müxtəlif siniflər üzrə eyni məzmunlu alt məzmun standartları əsasında fəaliyyətinin izlənilməsi (bacarıq səviyyələrinin qiymətləndirilməsi) üçün tərtib olunmuş rubrik nümunələri verilir və onların səviyyələri arasında əlaqənin yaradılması təklif olunur:

Məzmun xətti I. Odədlər və əməllər. I sinif üzrə:

a) əsas məzmun standart1: 1.1 ;

b) alt məzmun standart1: 1.1.3.

Alt məzmun standartı üzrə təlim məqsədi: 1.1.3 - şagird 20 dairəsində ədədləri oxumağı və yazmağı bacardığını nümayiş etdirir.

Qiymətləndirmə aspekti: təqdimetmə.

I sinifdə təhsilalanın 1.1.3. alt məzmun standartı üzrə müəyyən olunmuş təlim məqsədləri əsasında təyin edilən qiymətləndirmə aspekti üzrə fəaliyyətinin qiymətləndirilməsi üçün holistik rubrik nümunəsi verilir (cədvəl 2). 


\section{Holistik rubrik nümunəsi}

\begin{tabular}{|c|c|}
\hline $\begin{array}{c}\text { I } \\
\text { səviyyə }\end{array}$ & $\begin{array}{l}\text { Müəllimin köməyi ilə 20 dairəsində verilmiş ədədi əyani vəsait } \\
\text { və təsvirlərdən istifadə etməklə bir onluq və təkliklərə ayırır və } \\
\text { oxuyur. }\end{array}$ \\
\hline II & $\begin{array}{l}\text { 20 dairəsində verilən ədədi müxtəlif əyani vəsaitlərin köməyi ilə } \\
\text { bir onluq və təkliklərə ayırır, oxuyur və yazır. }\end{array}$ \\
səviyyə & $\begin{array}{c}20 \text { dairəsində rəqəmlərlə və sözlərlə verilmiş ədədləri onluq və } \\
\text { təkliklərə ayırmağı, oxumağ1, yazmağ1 və müəyyən situasiyalarda } \\
\text { istifadə olunmasını nümayiş etdirir. }\end{array}$ \\
səviyyə
\end{tabular}

II sinif üzrə: a) əsas məzmun standartı: 1.1; b) alt məzmun standart1: 1.1.1.

Alt məzmun standartı üzrə təlim məqsədi: 1.1.1 - şagird 100 dairəsində ədədləri oxumağı və yazmağı bacardığını nümayiş etdirir.

Qiymətləndirmə aspekti: nümayişetdirmə.

II sinifdə təhsilalanların 1.1.1. alt məzmun standartı üzrə müəyyən olunmuş təlim məqsədi əsasında təyin edilən qiymətləndirmə aspekti üzrə fəaliyyətinin qiymətləndirilməsi üçün holistik rubrik nümunəsi verilir (cədvəl 3).

\section{Holistik rubrik nümunəsi}

\begin{tabular}{|c|l|}
\hline $\begin{array}{c}\text { I } \\
\text { səviyyə }\end{array}$ & $\begin{array}{l}\text { 20 dairəsində ədədləri onluq və təkliklərə ayırır, oxuyur və yazır. } \\
\text { Müəllimin köməyi ilə 100 dairəsində verilən ədədi onluq və } \\
\text { təkliklərə ayırır, oxuyur və yazır. }\end{array}$ \\
\hline $\begin{array}{c}\text { II } \\
\text { səviyyə }\end{array}$ & $\begin{array}{l}100 \text { dairəsində verilən ədədi onluq və təkliklərə ayırır, oxuyur } \\
\text { və yazır. }\end{array}$ \\
\hline III & $\begin{array}{l}100 \text { dairəsində ədədi onluq və təkliklərlə ifadə etməyi, oxumağ1, } \\
\text { yazmağ1 və lazımi situasiyalarda istifadəni nümayiş etdirir. }\end{array}$ \\
səviyyə & $\begin{array}{l}100 \text { dairəsində ədədləri onluq və təkliklərlə ifadə etməyi, } \\
\text { oxumağ1, yazmağı müxtəlif situasiyalarda məqsədəuyğun } \\
\text { istifadəni nümayiş etdirir və izahat verir. }\end{array}$ \\
\hline IV \\
səviyyə
\end{tabular}

III sinif üzrə: a) əsas məzmun standart1: 1.1; b) alt məzmun standart1: 1.1.1. 
Alt məzmun standartı üzrə təlim məqsədi: 1.1.1 - şagird 1000 dairəsində ədədləri oxumağı və yazmağı bacardığını nümayiş etdirir.

Qiymətləndirmə aspekti: nümayişetdirmə.

III sinifdə təhsilalanların 1.1.1 alt məzmun standartı üzrə müəyyən olunmuş təlim məqsədi əsasında təyin edilən qiymətləndirmə aspekti üzrə fəaliyyətlərinin qiymətləndirilməsi üçün holistik rubrik nümunəsi verilir (cədvəl 4).

\section{Holistik rubrik nümunəsi}

\begin{tabular}{|c|l|}
\hline $\begin{array}{c}\text { I } \\
\text { səviyyə }\end{array}$ & $\begin{array}{l}100 \text { dairəsində verilən ədədləri onluq və təkliklərə ayırır, oxuyur } \\
\text { və yazır. Müəllimin köməyi ilə } 1000 \text { dairəsində verilən ədədi } \\
\text { mərtəbələrə ayırır, oxuyur və yazır. }\end{array}$ \\
\hline $\begin{array}{c}\text { II } \\
\text { səviyyə }\end{array}$ & 1000 dairəsində verilən ədədi mərtəbələrə ayırır, oxuyur və yazır. \\
\hline $\begin{array}{c}\text { III } \\
\text { səviyyə }\end{array}$ & $\begin{array}{l}1000 \text { dairəsində ədədi mərtəbələrə ayırmağ1, oxumağ1, yazmağ1 və } \\
\text { müəyyən situasiyalarda istifadəni nümayiş etdirir. }\end{array}$ \\
\hline $\begin{array}{c}\text { IV } \\
\text { səviyyə }\end{array}$ & $\begin{array}{l}1000 \text { dairəsində ədədləri mərtəbələrə ayırmağı, oxumağı, yazmağı, } \\
\text { müxtəlif situasiyalarda istifadəni nümunələr əsasında nümayiş } \\
\text { etdirir və izahat verir. }\end{array}$ \\
\hline
\end{tabular}

IV sinif üzrə: a) əsas məzmun standart1: 1.1; b) alt məzmun standart1: 1.1.1.

Alt məzmun standartı üzrə təlim məqsədi: 1.1.1 - şagird 1000000 dairəsində ədədləri oxumağı və yazmağı bacardığını nümayiş etdirir.

Qiymətləndirmə aspekti: nümayişetdirmə.

IV sinifdə təhsilalanların 1.1.1 alt məzmun standartı üzrə müəyyən olunmuş təlim məqsədi əsasında təyin edilən qiymətləndirmə aspekti üzrə fəaliyyətlərinin qiymətləndirilməsi üçün holistik rubrik nümunəsi verilir (cədvəl 5).

\section{Holistik rubrik nümunəsi}

\begin{tabular}{|c|l|}
\hline $\begin{array}{c}\text { I } \\
\text { səviyyə }\end{array}$ & $\begin{array}{l}\text { Odədləri 1000 dairəsində mərtəbələrə ayırır, oxuyur və yazır. } \\
\text { Müəllimin köməyi ilə verilən ədədi } 1000000 \text { dairəsində siniflərə } \\
\text { ayırı, oxuyur və yazır. }\end{array}$ \\
\hline II & Verilən ədədi 1000000 dairəsində siniflərə ayırır, oxuyur və yazır. \\
səviyyə & \\
\hline
\end{tabular}




\begin{tabular}{|c|c|}
\hline $\begin{array}{c}\text { III } \\
\text { səviyyə }\end{array}$ & $\begin{array}{l}1000000 \text { dairəsində ədədləri siniflərə ayırmağ } 1 \text {, oxumağ1 və } \\
\text { yazmağ1 nümunə əsasında nümayiş etdirir. }\end{array}$ \\
\hline $\begin{array}{l}\text { IV } \\
\text { səviyyə }\end{array}$ & $\begin{array}{l}1000000 \text { dairəsində ədədləri siniflərə ayırmağ1, oxumağ } \text { və } \\
\text { yazmağ1 nümayiş etdirir, zəruri izahları verir. }\end{array}$ \\
\hline
\end{tabular}

Yeni təhsil standartı və proqramlarının (kurikulumların) tətbiq olunduğu siniflərdə aparılan müşahidə və təhlillər nəticəsində müəllimlərin əksəriyyətinin riyaziyyatdan 1.1. əsas məzmun standart1, 1.1.1. alt məzmun standartları üzrə təlim məqsədlərinə uyğun qiymətləndirmə aspekti əsasında müxtəlif siniflər üzrə rubriklər hazırladıqları zaman siniflərarası (səviyyələrarası) əlaqəni nəzərə almadıqları, onu inkişaf etdirmədikləri aydın olmuşdur [Ümumtəhsil məktəblərinin I-IV sinifləri üçün fənn kurikulumları, 2008].

Biz şagirdin eyni məzmun xəttinə aid əsas məzmun standartının müxtəlif siniflərə aid müvafiq alt məzmun standartları üzrə fəaliyyətinin qiymətləndirilməsi üçün rubriklərin əsas məzmun standartı $\rightarrow I(I I, I I$, ..., X) sinif üzrə alt məzmun standartı $\rightarrow$ təlim məqsədi $\rightarrow$ qiymotlondirmo aspekti $\rightarrow$ qiymotlondirmo soviyyalori (rubrik) $\rightarrow$ II (III, IV, ..., XI) sinfo aid alt mozmun standartı $\rightarrow$ təlim məqsədi $\rightarrow$ qiymətlondirmo aspekti $\rightarrow$ qiymotlondirmo səviyyəlori (rubrik, bu halda əvvolki sinfin səviyyəsi nozərə alınır) $\rightarrow$... alqoritmi əsasında hazırlanmasını və onların siniflər üzrə səviyyələri arasında əlaqənin aşağıdakı cədvəl əsasında qurulmasını təklif edirik (cədvəl 6).

Cadval 6

\begin{tabular}{|c|l|l|l|l|l|l|l|l|l|l|l|l|l|}
\hline Sinif & \multicolumn{10}{|l|}{ Səviyyələr } \\
\hline I & I & II & III & IV & & & & & & & & & \\
\hline II & & & & I & II & III & IV & & & & & & \\
\hline III & & & & & & & I & II & III & IV & & & \\
\hline IV & & & & & & & & & & I & II & III & IV \\
\hline
\end{tabular}

Göründüyü kimi, “I. Әdədlər və əməllər” məzmun xəttinin 1.1. əsas məzmun standartının I-IV siniflər üzrə eyni alt məzmun standartlarını nəzərdən keçirdikdə, ikinci sinifdən başlayaraq, hər sonrakı il sinifdə reallaşdırılan alt məzmun standartının əvvəlki sinifdə reallaşdırılmış məzmun standartının üfüqi və şaquli davamı olduğu aydınlaşır. Bu baxımdan, siniflər üzrə şagird fəaliyyətinin alt məzmun standartları üzrə ardıcıl qiymətləndirilməsi üçün tərtib olunan rubrik səviyyələrinin ikinci sinifdən başlayaraq, hər sonrakı sinifdə təhsilalanın bacarıq 
səviyyəsinin onun əvvəlki sinifdə nail olmalı olduğu bacarıq səviyyəsi nəzərə alınmaqla tərtib olunması məqsədəuyğun hesab edilir ["Ümumi təhsil pilləsində təhsilalanların attestasiyasının (məktəbdaxili qiymətləndirmə) aparılması Qaydas1" 2018].

Göstərilənləri nəzərə alaraq, şagirdin II (III-IV) sinfə aid I səviyyə üzrə bacarıq səviyyəsinin onun I (II-III) sinifdə nail olmalı olduğu ən yüksək (IV) bacarıq səviyyəsi ilə eyni olmasını təklif edirik. Bununla belə, ikinci sinifdən başlayaraq, müəllim sinifdə təhsil alan şagirdlərin ümumi bilik və bacarıq səviyyələrindən asılı olaraq, sonrakı sinifdə şagirdin I səviyyə üzrə bacarıq səviyyəsini onun əvvəlki sinifdə nail olmalı olduğu III (və ya II) bacarıq səviyyəsini də qəbul edə bilər. Bu, həqiqətən də belə olmalıdır. Ona görə ki, riyaziyyatın tədrisində horizontal və vertikal əlaqələr nəzərə alınır və hər sonrakı sinifdə (məsələn, ikinci) öyrənilənlər əvvəlki (birinci) sinifdə öyrənilənlərin horizontal və vertikal davamı kimi verilir. Biz təlim prosesində şagirdin qiymətləndirilən bacarıqlarının səviyyələrinin düzgün müəyyən olunmasını təhsilin keyfiyyətinin yüksəldilməsinə ciddi təsir edən mühüm amil hesab edirik.

\section{Natica / Conclusion}

Qeyd edək ki, bu problemlər ibtidai təhsil səviyyəsində çox sadə şəkildə öz həllini tapdığ halda, bəzən ümumi orta və tam orta təhsil səviyyələrində müəyyən çətinliklərlə qarşılaşırıq. Belə ki, müəyyən mənada ibtidai təhsil səviyyəsində şagirdləri birinci sinifdə qəbul edən müəllim onlarla dörd il ardıc1l təmasda olduğu üçün (onlara nəyi hans1 səviyyədə öyrətdiyini və onların hans1 sinifdə hans1 səviyyədə bilik əldə etdiklərini, hansı səviyyədə bacarıqlara yiyələndiklərini bildiyi üçün) hər növbəti dərs ilində onların fəaliyyətini izləyərkən əvvəlki sinifdə bacarıq səviyyələrini nəzərə alır, sonrakı sinifdə onu düzgün müəyyən edə bilir. Bəzi hallarda isə ümumi və ya tam orta təhsil səviyyəsində dərs aparan müəllim şagirdin əvvəlki siniflərdə müəyyən məzmun xətti üzrə hər hans1 əsas məzmun standartının hansı alt məzmun standartı üzrə nələrə nail olduğunu bilməməsi və ya onu nəzərə almaması səbəbindən müəyyən yanlışlıqlara, bəzən təkrara yol verir, bəzi hallarda mücərrədliyə varır və nəticə etibarı ilə təlim vəzifəsini - təlim məqsədlərini düzgün yerinə yetirmir. Bu baxımdan, ümumi və tam orta təhsil səviyyələrində dərs aparan fənn müəllimlərinin şagirdlərin əvvəlki təhsil səviyyələrində və ya siniflərdə hansı məzmun xətti üzrə bilik və bacarıqlara nail olduqlarını, əsas məzmun standartlarının müvafiq alt standartları üzrə nail olacaqları bilik və bacarıq səviyyələri barədə məlumatlı olmalarını zəruri hesab edirik. 


\section{http://ppe-journal.edu.az}

Məqalənin aktuallı̆̆ı. Ümumtəhsil məktəblərində şagird nailiyyətlərinin qiymətləndirilməsi formaları günün aktual mövzularından biridir. Ümumtəhsil məktəblərində riyaziyyat fənnindən şagirdin fəaliyyətinin əsas məzmun standartlarının müvafiq alt məzmun standartları (ardıcıl siniflər) üzrə izlənilməsi və bacarıq səviyyəsinin qiymətləndirilməsi üçün rubriklərin hazırlanması, bu zaman fənn üzrə horizontal və vertikal əlaqələrin nəzərə alınması şagird nailiyyətlərinin müasir qiymətləndirmə modellərindən biri kimi gündəmə gəlir.

Məqalənin elmi yeniliyi. Məqalədə ilk dəfə olaraq riyaziyyat fənnindən şagird fəaliyyətinin izlənilməsi üçün rubrik tərtib edərkən əsas məzmun standartının əvvəlki sinif(lər)də reallaşdırılmış müvafiq alt məzmun standartları üzrə bacarıq səviyyələrinin nəzərə alınması üçün model təklif olunur.

Məqalənin praktik əhəmiyyəti. Müəllim şagird bacarıqlarının riyaziyyat fənni üzrə əsas məzmun standartlarının siniflər üzrə alt məzmun standartları üzrə qiymətləndirilməsi zamanı vertikal əlaqənin əhəmiyyətini başa düşür. Bu isə təhsilin keyfiyyətinin yüksəldilməsini təmin edir.

\section{İstifadə olunmuş ədəbiyyat / References}

1. Azərbaycan Respublikasının ümumi təhsil sistemində Qiymətləndirmə Konsepsiyas1. (2009). Bak1.

2. Azərbaycan Respublikasında təhsilin inkişafı üzrə Dövlət Strategiyası. (2013). Bak1.

3. Ümumtəhsil məktəblərinin I-IV sinifləri üçün fənn kurikulumları. (2008). Bak1.

4. Ümumi təhsilin fənn standartları (I-XI siniflər). (2012). Bak1.

5. Ümumi təhsil məktəblərində məktəbdaxili qiymətləndirmənin aparılmasına dair müvəqqəti Təlimat. (2013). Bak1.

6. "Ümumi təhsil pilləsində təhsilalanların attestasiyasının (məktəbdaxili qiymətləndirmə) aparılması Qaydası". (2018). Bak1.

7. Mahmudov N.M., Mustafayeva G.C. və başqaları. (2014). İbtidai siniflərdə şagirdlərin riyaziyyatdan bacarıq səviyyələrinin qiymətləndirilməsi üçün rubrik nümunələri. Bakı.

8. Шакиров Р.Х., Кадыралиева М.Ф., Сахарова Г.Н., Буркитова А.А. (2012). Формативное оценивание на уроках математики. (практическое пособие для учителя). Бишкек, “Билим”. 